\title{
The effects of summer exposure to ozone on the frost hardiness after the vegetation period of Norway and Sitka spruce seedlings
}

\author{
P.W. Lucas
}

Institute of Environmental and Biological Sciences, (Division of Biological Sciences), University of Lancaster, Lancaster, LA1 4YQ. U.K.

\section{Introduction}

No single cause has been identified to explain the decline of coniferous trees in some high-elevation forests in Europe and parts of the USA, but a consensus view among researchers is that the observed changes are associated with air pollutants. Air pollutants are, however, only one of a variety of environmental stresses which may affect the physiology of trees and which could predispose or incite damage. In those areas where forest declines are occurring, daily mean ozone concentrations are often above $100 \mu \mathrm{g} \cdot \mathrm{m}^{-3}$. Exposure to elevated concentrations of ozone is known to damage cell membranes (Heath, 1980). Since loss of membrane integrity is thought to be the major cause of frost injury (Levitt, 1980), there are good physiological reasons to believe that ozone could increase the sensitivity of plants to freezing injury.

The objectives of the present study were to investigate whether long-term exposure to ozone during the summer af- fected the frost hardening and dehardening of Norway spruce (Picea abies L. Karst) and Sitka spruce ( $P$. sitchensis [Bong] Carr) such that their susceptibility to frost damage was increased.

\section{Materials and Methods}

Ozone fumigation and growth measurements

At the beginning of May 1987, $252 \mathrm{yr}$ old seedlings of each species were assigned randomly to each of 4 large-scale fumigation chambers, described previously by Lucas et al. (1987). Fumigation of the seedlings began on 1 June 1987 and continued until 11 September 1987. In two of the chambers, trees were exposed to ozone for $7 \mathrm{~h}$ each day (08:00-15:00) for $5 \mathrm{~d}$ per wk at an average hourly concentration of $140 \mu \mathrm{g} \cdot \mathrm{m}^{-3}$; the remaining chambers received charcoal-filtered air and acted as controls.

\section{Frost hardening and freezing tests}

At the end of the fumigation, the trees remained in the chambers to frost harden until lateral shoot elongation had ended and minimum air 
temperatures had fallen below $10^{\circ} \mathrm{C}$. The first freezing test was therefore not carried out until the 20 October 1987.

On each sampling occasion, current year's lateral shoots were detached from each of 5 trees of each species and from each chamber. Two shoots, approximately $4 \mathrm{~cm}$ in length, from each tree were frozen in an unlit programmable freezing cabinet as described by Lucas et al. (1988). Separate batches of shoots were subjected to separate freezing tests in the range -5 to $-25^{\circ} \mathrm{C}$, with cooling and warming rates of $5^{\circ} \mathrm{C}$ $\mathrm{h}^{-1}$ and $10^{\circ} \mathrm{C} \mathrm{h}^{-1}$, respectively. The preset target temperature was held for $3 \mathrm{~h}$. After freezing, the middle portion of each shoot was placed in a $20 \mathrm{ml}$ polypropylene vial and $15 \mathrm{ml}$ of deionised water were added. The vial was capped, shaken and stored at $6^{\circ} \mathrm{C}$. Solution conductivity was measured after $24 \mathrm{~h}$ using a platinum electrode. The samples were stored at $6^{\circ} \mathrm{C}$ for a further $5 \mathrm{~d}$ and the conductivity was again measured. After this second reading, the shoots were stored at $6^{\circ} \mathrm{C}$ and after $14 \mathrm{~d}$ scored for visual damage $(0=$ no damage, $1=<50 \%$ damaged, $2=>50 \%$ damaged, $3=$ shoot brown, assumed dead). The shoots + vials were then autoclaved and the total conductivity $\left(C_{\infty}\right)$ of the solution determined. Based on the assumption that the rate of leakage of electrolytes from a detached shoot is controlled by diffusion, the conductivity of the solution at any time $\left(C_{1}\right)$ can be described by a first-order reaction equation: $C_{t}=C_{\infty}\left(1-\mathrm{e}^{-k t}\right)$.

By logarithmic transformation of the above equation and substitution of the measured conductivity values, the rate of change in conductivity or normalised leakage rate $(k)$ was calculated. A comparison of $k$ values with visible damage showed for both species of spruce that shoots with $k$ values $\geq 0.35 \% \mathrm{~h}^{-1}$ would be killed.

\section{Results}

By the time of the first freeze test on 20 October 1987 (Fig. 1), the Norway spruce had hardened to a temperature of about $-19^{\circ} \mathrm{C}$, although there was a delay in hardening in those shoots that had been exposed to ozone. For the Sitka spruce, there was no effect of pollutant exposure on the timing of frost hardiness attained by the shoots but, compared to the Norway shoots at this time, there was a quite marked difference (approximately $12^{\circ} \mathrm{C}$ ) in the depth of hardiness attained.

Between 20 October and 24 November, the Norway shoots hardened at a rate of ca $0.3^{\circ} \mathrm{C} \mathrm{d}^{-1}$ compared to the Sitka which hardened at a rate of $c a 0.2^{\circ} \mathrm{C} \mathrm{d}^{-1}$ and had acquired at least a further $5-6^{\circ} \mathrm{C}$ of hardiness. The Norway shoots may, however, have hardened to much lower temperatures, as the minimum temperature which could be attained by the freezing chamber was only $-25^{\circ} \mathrm{C}$. For this second freezing test and for the tests made at later dates, there were no significant effects of ozone on the freezing sensitivity of shoots from either species of spruce.

Over the period 24 November-20 January, there was no change in the leakage rate of the Norway spruce shoots and it is probable that they were hardy to temperatures considerably in excess of the minimum freezing temperature shown (Fig. 2). In contrast, the Sitka shoots had only attained a further $3^{\circ} \mathrm{C}$ of hardiness during this time.

By mid-May, bud burst had occurred in all the trees and a freezer test at this time showed that shoots of both species had dehardened to temperatures between -5 and $-10^{\circ} \mathrm{C}$ (Fig. 3).

\section{Discussion and Conclusions}

Exposure to ozone delayed the frost hardening of Norway spruce shoots during mid-autumn. Similar results for Norway spruce have also been observed by other researchers, both with ozone (Barnes and Davison, 1988) with $\mathrm{SO}_{2}$ and $\mathrm{NO}_{2}$ in combination (Freer-Smith and Mansfield, 1987) and with acid mist (Cape et al., 1988). The results of the present study, 


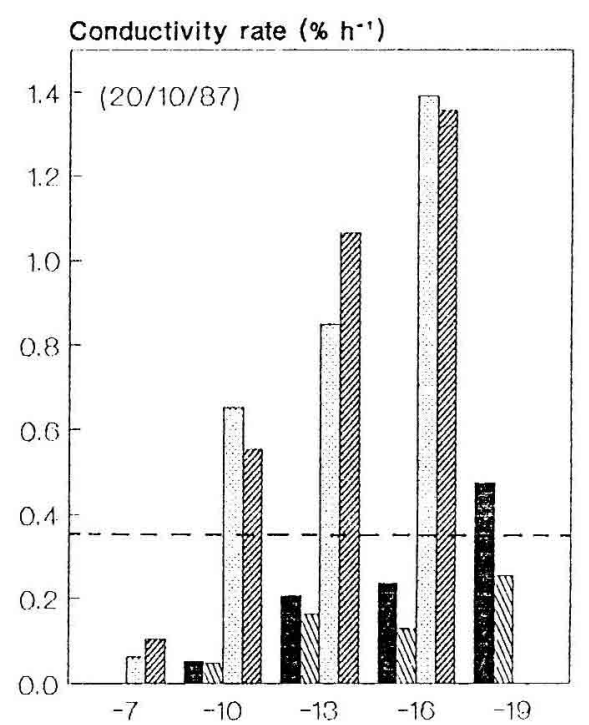

Fig. 1. Temperature $\left({ }^{\circ} \mathrm{C}\right)$

Figs. 1-3. The effects of ozone on the frost hardiness of detached shoots of Norway and Sitka spruces. The dotted line represents the conductivity rate at which shoots are killed. Sampling dates are shown in paren. theses. wata : control (Sitka); $: 140 \mu \mathrm{g} / \mathrm{m}^{3} \quad \mathrm{O}_{3}$ (Sitka); : control (Norway); : $140 \mu \mathrm{g} / \mathrm{m}^{3} \quad \mathrm{O}_{3}$ (Norway).

therefore, appear to support the hypothesis that air pollutants may predispose Norway spruce trees to damage by frosts.

For Sitka spruce, however, there were no effects of ozone on delayed frost hardening and the results differ from those reported previously by Lucas et al. (1988), in which spruce seedlings were exposed to a similar concentration of ozone using the same fumigation system. In this case, although there was no effect of the pollutant on the attainment of deep winter hardiness, the sensitivity of detached shoots to autumn frosts was found to be increased. At present it is difficult to offer an explanation for the different results between the

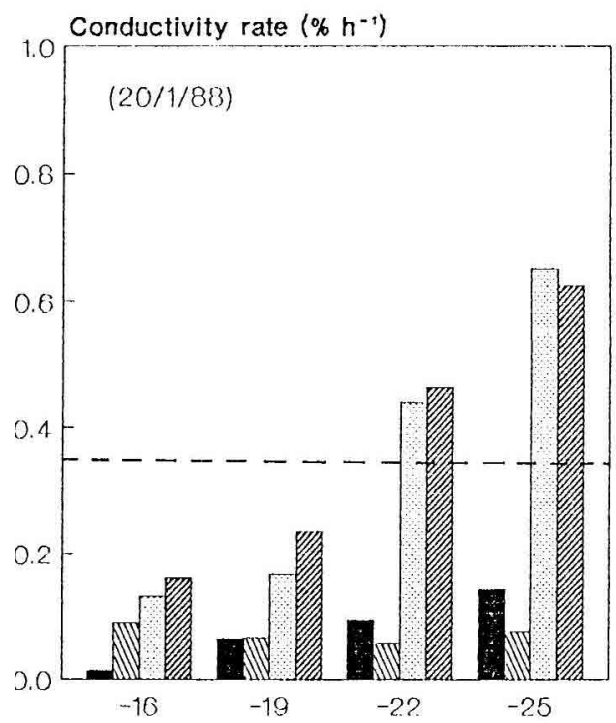

Fig. 2. Temperature $\left({ }^{\circ} \mathrm{C}\right)$

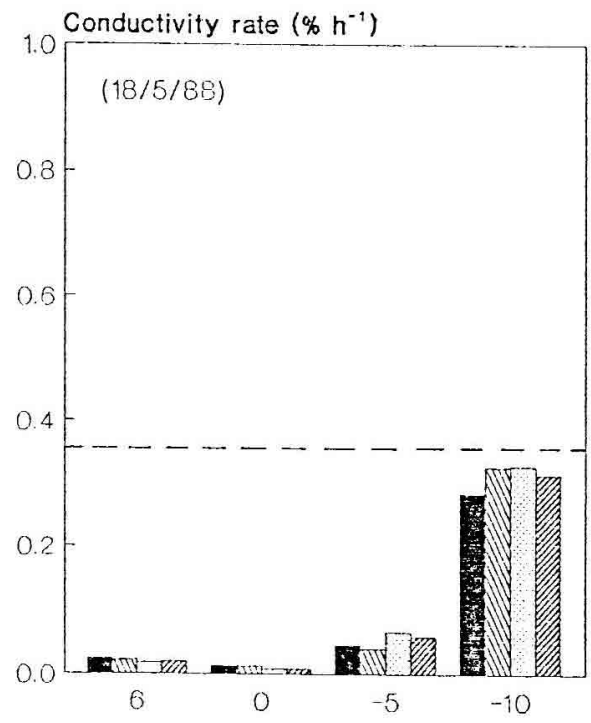

Fig. 3. Temperature $\left({ }^{\circ} \mathrm{C}\right)$

two experiments, but other environmental factors may be involved in modifying the plant's response to the ozone. 


\section{Acknowledgments}

This work was supported in part by the UK Department of the Environment, the Commission of the European Communities, the NE Forest Experiment Station of the USDA Forest Service and the US Environmental Protection Agency, as part of the National Acid Precipitation Assessment Program.

\section{References}

Barnes J.D. \& Davison A.W. (1988) The influence of ozone on the winter hardiness of Norway spruce. New Phytol. 108, 159-166

Cape J.N., Sheppard L.J., Leith I.D., Murray M.B., Deans J.D. \& Fowler D. (1988) The effects of acid mist on the frost hardiness of red spruce seedlings. Aspects Appl. Biol. 17, 141149
Freer-Smith P.H. \& Mansfield T.A. (1987) The combined effects of low temperature and $\mathrm{SO}_{2}+\mathrm{NO}_{2}$ pollution on the new season's growth and water relations of Picea sitchensis. New Phytol. 106, 225-237

Heath R.L. (1980) Initial events in injury to plants by air pollutants. Annu. Rev. Plant Physiol. 31, 395-401

Levitt J. (1980) Responses of plants to environmental stresses. In: Physiological Ecology Series. (2nd edn. Vol. 1) Chilling, Freezing and High Temperature Stresses. Academic Press, New York, pp. 254-262

Lucas P.W., Cottam D.A. \& Mansfield T.A. (1987) A large-scale fumigation system for investigating interactions between air pollution and cold stress on plants. Environ. Pollut. 43, 15-28

Lucas P.W., Cottam D.A., Sheppard L.J. \& Francis B.J. (1988) Growth responses and delayed winter hardening in Sitka spruce following summer exposure to ozone. New Phytol. 108, 495-504 